\title{
FREQUENCY OF CONGENITAL BIRTH DEFECTS IN NEWBORN BABIES BORN AT HYDERABAD, SINDH.
}

1.

Assistant Professor Community Medicine

Isra University Hospital, Hyderabad, Sindh, Pakistan

2. MBBS, MD (Pediatrics) Assistant Professor Pediatric Isra University Hospital,

Assistant Professor

Liaquat University Medical Health

Science Jamshoro.

Correspondence Address:

Dr. Amir Memon

Assistant Professor Pediatrics

Isra University Hospital,

Hyderabad, Sindh, Pakistan.

aamir_memon1@hotmail.com

Article received on:

11/03/2019

Accepted for publication:

$15 / 10 / 2019$

\begin{abstract}
Sajjad Ali Kazi ${ }^{1}$, Muhammad Aamir Memon ${ }^{2}$, Abdul Hameed Radhan ${ }^{3}$
\end{abstract}
ABSTRACT... Objectives: This study has been conducted in a tertiary care hospital to observe the frequency of congenital birth defects in newborn babies born at, Hyderabad, Sindh. Study Design: Observation study. Setting: Departments of Obstetrics and Pediatrics, Isra University Hospital, Hyderabad. Period: Two years from 2016 to 2018. Material \& Methods: All the pregnant women irrespective of their parity and were included in the study after getting informed and written consent from their family heads and after the approval from Hospital's ethical committee. We have used SPSS version 21.0 software for both data entering and analysis. All the continuous variables were analyzed using student t test and categorical variables were analyzed using chi-square test. P-value of $\leq 0.05$ was taken as statistically significant. Results: A total of 150 pregnant women were included in our study with their mean age and SD was $26.72 \pm 7.07$ years and the mean years of marriage were $5.95 \pm 6$ years. Most of the women were multiparous (47\%), as compared to nulliparous and grandmultiparous, $33 \%$ and $20 \%$, respectively. The prevalence of congenital birth defect was $11.3 \%$, of these $30 \%$ had CNS malformations followed by $30 \%$ with gastrointestinal, $24 \%$ musculoskeletal, $12 \%$ genitourinary and $4 \%$ had ear malformations. Conclusion: The interfamily marriages (consanguineous marriages) are more common than outside family in study population. The frequency of birth defects was more than i-e: twice higher in interfamily marriages than outside family marriages.

Key words: $\quad$ Congenital Birth Defects, Interfamily Marriages, Sindh, Pakistan.

Article Citation: Kazi SA, Memon MA, Radhan AH. Frequency of congenital birth defects in newborn babies born at Hyderabad, Sindh. Professional Med J 2020; 27(4):707-710. DOI: 10.29309/TPMJ/2020.27.04.3400

\section{INTRODUCTION}

Any structural or functional anomaly that has occurred during intrauterine life due to any cause is called congenital birth defect. The diagnosis of most of the congenital anomalies can easily be made during prenatal period and if left undiagnosed can be diagnose after birth. There are certain diseases which cannot be diagnosed during prenatal period and after birth but they are diagnosed during infancy such as hearing defects. $^{1}$

The burden of congenital diseases varies hugely depending upon the area and country's development. The prevalence can be as low as $39.1 / 1,000$ live births in developed countries and can be as high as $82 / 1,000$ live births in developing countries including Pakistan. ${ }^{2}$ It has been observed that congenital heart diseases cyanotic and acyanotic heart disease are the most common cause of birth defects followed by the neural tube defects such as down syndrome. ${ }^{1}$ The prevalence of congenital birth defects in Pakistan ranging from $6 \%$ to $9 \%$ of all perinatal deaths. ${ }^{3,4}$ The outcome of such children is reduced due to malfunctioning of any of the body normal mechanisms and they usually die during early childhood. ${ }^{5}$

More than $50 \%$ of the congenital birth defects do not have any underlying identifiable cause and hence called as sporadic. ${ }^{6}$ Nearly one third of children have multifactorial involvement in causing congenital birth defects ranging from genetic factor and environmental causes. In developing countries like Pakistan roughly around $10 \%$ have environmental cause such as predisposition of mother to infections which ultimately leads the children to affected growth. On the other hand less common cause of congenital anomaly 
is the involvement of generic cause such as chromosomal disorders. ${ }^{7}$

Some social classes mostly from Middle East, Africa, and Asia including Pakistan and India still prefer cousin marriages which accounts for more than $20 \%$ of all marriages in Pakistan. It has been observed that interfamily marriages are also the important cause of birth defects and increase chances has been seen in consequent marriages. $^{7}$

Cousin marriages or interfamily marriages are very common especially in Sindh culture but unfortunately congenital birth defects caused by this is not available. ${ }^{8}$ That is why this study has been conducted to scientifically determine the true burden of congenital birth defects in People residing at Sindh.

\section{MATERIAL AND METHODS}

This was a prospective observation study conducted in the Departments of Obstetrics and Pediatrics, Isra University Hospital, Hyderabad between the periods of two years from 2016 to 2018.

All the pregnant women irrespective of their parity and were included in the study after getting informed and written consent from their family heads and after the approval from Hospital's ethical committee. A detailed history was taken from all the pregnant women and thoroughly examination was also performed before and after the delivery to look for any congenital birth defect. All the data were recorded using predesigned questionnaire and entered into SPSS version 21 for data analysis. All the continuous variables were analyzed using student $t$ test and categorical variables were analyzed using chi-square test. P-value of $\leq 0.05$ was taken as statistically significant.

\section{RESULTS}

After meeting inclusion and exclusion criteria a total of 150 pregnant women were included in our study with their mean age and SD was $26.72 \pm 7.07$ years, mean years of marriage were $5.95 \pm 6$ years, and mean weight of mother was $65.43 \pm 8.07 \mathrm{~kg}$ and mean height of mother was $1.01 \pm 0.20$ meters. Most of the women were multiparous (47\%), as compared to nulliparous and grandmultiparous, $33 \%$ and $20 \%$, respectively. About $44 \%$ of mothers were more than 30 years of age whereas $56 \%$ of the study participants were below the age of 30 years.

Most of the study participants were married to their cousins $(64 \%, \mathrm{~N}=95)$ and among them most were Muslims (72.6\%) and $45.5 \%$ of them were delivered with normal vaginal delivery. The prevalence of congenital birth defect was $11.3 \%$, of these $30 \%$ had CNS malformations followed by $30 \%$ with gastrointestinal, $24 \%$ musculoskeletal, $12 \%$ genitourinary and $4 \%$ had ear malformations as shown in Table-I \& II.

\begin{tabular}{|c|c|c|c|c|}
\hline $\begin{array}{l}\text { Congenital } \\
\text { Malfor- } \\
\text { mations }\end{array}$ & $\begin{array}{l}\text { Fre- } \\
\text { quency }\end{array}$ & $\begin{array}{c}\text { Per- } \\
\text { centage }\end{array}$ & $\begin{array}{l}\text { Chi } \\
\text { square } \\
\text { Value }\end{array}$ & P-Value \\
\hline Yes & 17 & 11.3 & \multirow{3}{*}{41.89} & \multirow{3}{*}{0.001} \\
\hline No & 133 & 88.7 & & \\
\hline Total & 150 & 100.0 & & \\
\hline
\end{tabular}

\begin{tabular}{|l|c|}
\hline CNS & 1 \\
\hline Down Syndrome & 1 \\
\hline Microcephaly & 2 \\
\hline Hydrocephalus & 1 \\
\hline Meningomyelocele & \\
\hline Genitourinary & 1 \\
\hline Undescended Testis & 1 \\
\hline Ambiguous Genitalia & \\
\hline Musculoskeletal & 1 \\
\hline Club Foot & 2 \\
\hline Polydactyly & 1 \\
\hline Bradydactyly & \\
\hline Gastro Intestinal & 3 \\
\hline Clift Lip & 2 \\
\hline Cleft Palate & \\
\hline Ear & 1 \\
\hline Low Set Ear & \\
\hline Table-II. Categorizations of congenital malformations. \\
\hline
\end{tabular}




\section{DISCUSSION}

Both family and to the parents if a child born with congenital disease it will cause burden to the family and the child will suffer it from whole life. It is estimated that more than 800 thousand children born with congenital birth defects each year throughout the world. Among all these children, more than 30,0000 die before reaching the age of five years while remaining suffer from unbearable physical and mental disability. ${ }^{9}$ Because of huge disease burden the researchers are working to reduce the incidence of congenital birth defects by advancing in the medical technology by which early diagnosis can be made and possible preventive measures can be taken. ${ }^{10}$

In a recent medical advances in which detection of congenital anomalies is far easier than before but still in developing countries due to lack of facilities the prevalence of these diseases has still on rise compared to other developed countries like America. ${ }^{11}$

Our study is one of the most important studies published in this area of interest; the overall burden of congenital anomalies shown in our study was $11.3 \%$, which is far greater if we look at the social and economical burden. Rest of the congenital malformations such as gastrointestinal $(30 \%)$, musculoskeletal (24\%), genitourinary (12\%), and least common malformation was of ear $(4 \%)$. Both national and international data has shown the congenital malformations but with different frequencies. An international study which was conducted by Asendi and Colleagues has shown the most common congenital malformation was seen in gastrointestinal tract and nervous system, which is differ from our study..$^{12}$ In a national study which was conducted by Fouzia $P$ and colleagues in Karachi has shown that Neural Tube Defect was the most common anomaly and accounted for more than $65 \%$ which is. ${ }^{13}$ The same findings were observed in a study conducted at Spain. ${ }^{14}$

The myth behind the high prevalence of congenital malformation was cousin marriages and the prevalence is even higher where these marriages are common like Pakistan. Our study has shown the prevalence of interfamily marriage is $64 \% .{ }^{15} \mathrm{~A}$ slight higher prevalence of interfamily marriage $(80 \%)$ has been observed in Peshawar but Northern Area of India has shown the interfamily marriage is quite different $(1-4 \%)^{16}$, this is because of religious constraints which refrain them from interfamily marriages. ${ }^{17,18}$

The prevalence of interfamily birth defect is varying in different regions like in Pakistan it is higher $(11 \%)$ and in developed countries it is $(6 \%) .{ }^{19}$ The variation could be due to lack of medical facilities which play an important role in diagnosing prenatal diagnosis of congenital diseases.

\section{CONCLUSION}

The interfamily marriages (consanguineous marriages) are more common than outside family in study population. The frequency of birth defects was more than i-e: twice higher in interfamily marriages than outside family marriages. This study found $11.3 \%$ congenital anomalies. However, the Central Nervous System (Hydrocephalus) \& GIT defects (Cleft lip) were observed as more common congenital abnormalities.

Copyright@ 15 Oct, 2019.

\section{REFERENCES}

1. WHO congenital anomalies, fact sheet Updated September 2016.

2. Conway H. Effect of supplemental vitamin therapy on the limitation of incidence of cleft lip and palate in humans. Plast Reconst Surg. 1958; 22:450-3.

3. Kucik JE, Alverson CJ, Gilboa SM, Correa A. Racial/ ethnic variations in the prevalence of selected major birth defects, 1994-2005. Public Health Rep. 2012; 127:52-61.

4. Korejo R, Bhutta S, Noorani KH, Bhutta ZA. An audit and trends of perinatal mortality at the Jinnah Postgraduate Medical Centre, Karachi. J Pak Med Assoc 2007; 57: 168-71.

5. Rehman A, Fatima S, Soomro N. Frequency of congenital anomalies and associated maternal risk factors in the lower socioeconomic groups. Pak J Surg 2006; 22: 169-73. 36. 
6. Khan AA, Khattak TA, Shah SHA, Roshan E, Haq AU. Pattern of congenital anomalies in the Newborn. $J$ Rawalpindi Med Coll 2012; 16(2):171-3.

7. Majeed-Saidan MA, Ammari AN, Al Hashem AM. Al Rakaf MS, Shoukri MM, Garne E, et al. Effect of consanguinity on birth defects in Saudi Women: Results from a nested case-control study. Birth Defects Research (Part A) 2015; 103:100-4.

8. Bittles A. 2001. Consanguinity and its relevance to clinical genetics. Clin Genet 60:89-98.

9. Jugessur A, Lie RT, Wilcox AJ. Variants of developmental genes (TGFA, TGFB3, and MSX1) and their associations with orofacial clefts: A caseparent triad analysis. Genet Epidemiol. Apr 2003; 24(3):230-9.

10. George TM, Fagan LH. Adult tethered cord syndrome in patients with postrepairmyelomeningocele: An evidence-based outcome study. J Neurosurg. Mar 2005; 102(2 Suppl):150-6.

11. Dobyns JH, Doyle JR, Von Gillern TL, Cowen NJ. Congenital anomalies of the upper extremity. Hand Clin. Aug 1989; 5(3):321-42; discussion 339-340.

12. Asindi, Hifzi IA. Major congenital malformations among Saudi infants admitted to Asir Central hospital. Ann Saudi Med. 1997; 17:250-3.
13. Fouzia $P$, Subhana $T$. Frequency and pattern of distribution of congenital anomalies in the newborn and associated maternal risk factor. JCPSP 2007; 17 : 340-343.

14. Gelineau-van Waes, J., Finnell, R.H. Genetics of neural tube defects, Semin Pediatr Neurol, 2001, 8(3), pp. 160-4.

15. Khan A, Zuhaid M, Fayaz M, Ali F, Khan A, Raza Ullah, Zafar $\mathrm{J}$ et al Frequency of congenital anomalies in newborns and its relation to maternal health in a Tertiary Care Hospital in Peshawar, Pakistan. The International Journal of Medical Students 2014, 2(2):3740.

16. Izharullah - Published Oct 15, 2015. Pak J Med Sci 2011 Vol.27 No 1.

17. Bittles $\mathrm{AH}$. Global prevalence of consanguinity. Pak J Med Sci 2011 Vol.27 No 1.

18. Sarkar S, Patra C, Dasgupta MK, Nayek K and Karmakar $P R$. Prevalence of congenital anomalies in neonates and associated risk factors in a Tertiary Care Hospital in Eastern India. J Clin Neonatol. 2013 Jul-Sep; 2(3): 131-134.

19. Bradford study finds higher birth defect risk in married cousins, 4 July 2013.

\begin{tabular}{|c|l|l|l|}
\hline \multicolumn{3}{|c|}{ AUTHORSHIP AND CONTRIBUTION DECLARATION } \\
\hline Sr. \# & \multicolumn{1}{|c|}{ Author(s) Full Name } & Contribution to the paper & Author(s) Signature \\
\hline 1 & Sajjad Ali Kazi & Idea, biostatic work. & \\
\hline 2 & M. Aamir Memon & Paper writing. & \\
\hline 3 & Abdul Hameed Radhan & Data collection. \\
\hline
\end{tabular}

